$$
\begin{aligned}
& \text { SB273 } \\
& \text { I 4M } 23
\end{aligned}
$$




\section{Date Due}
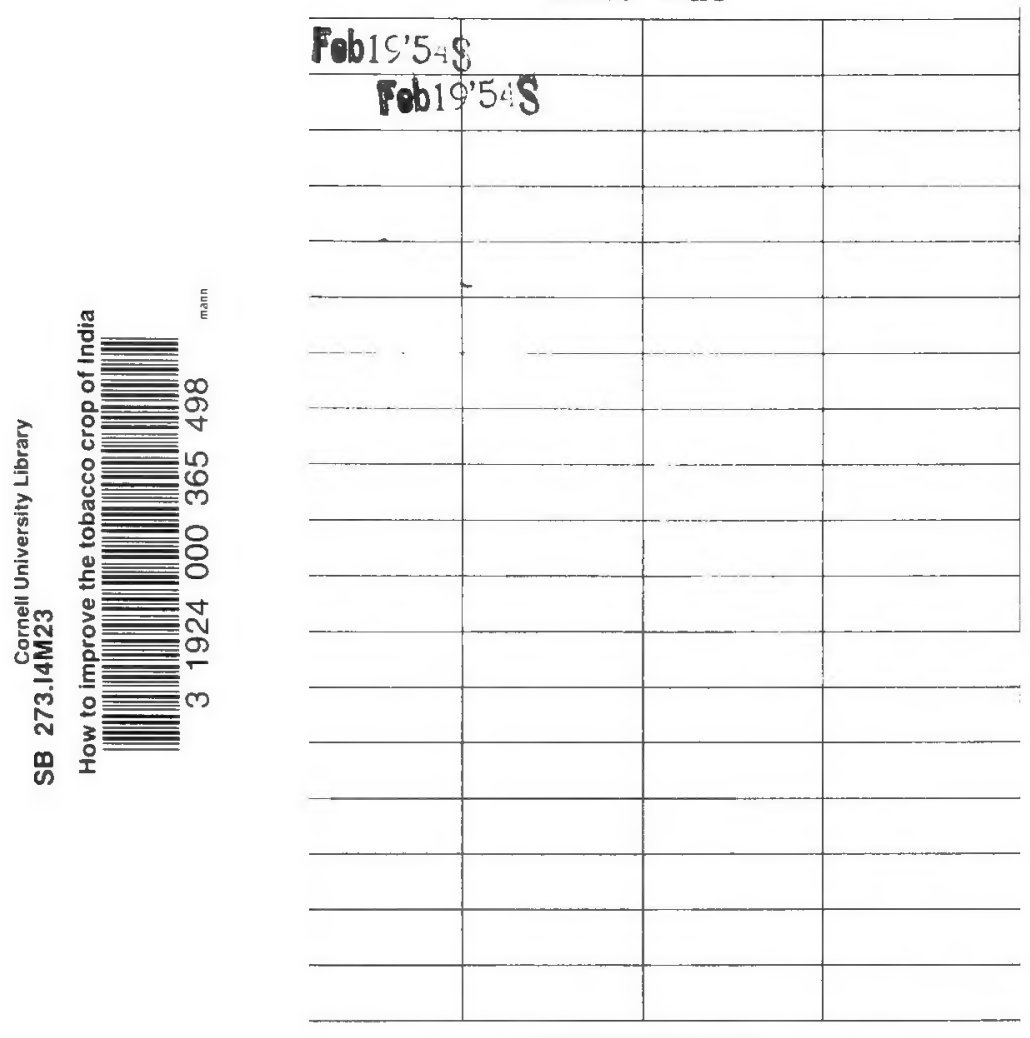

Library Bureau Cat, No. 1137

At Cornell dHubersitp Itbaca, 的. 旦.

II ibrarp 


\section{Cornell University Library}

The original of this book is in the Cornell University Library.

There are no known copyright restrictions in the United States on the use of the text. 


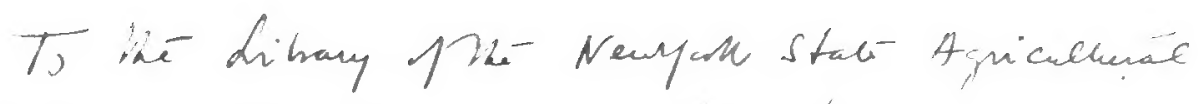
colege wita all gerde wis hes from

1., De haj undur Assis tant settlement office. Cooch Behar, India 15th Nwembr, 1915 



\title{
HOW TO IMPROVE THE TOBACCO CROP OF INDIA
}

\author{
BY \\ I. B. De Majumdar, \\ B.A., M.Sc. Agr. (Cornell, New York) \\ Scholar of "the Aswouation for the Alduncement of \\ Scientific and Iudustrial Education of Indiats., \\ and late Superintendent of the Agricultural \\ Deportment of Cooch Behar
}

WITH AN INTRODUCTION

BY

Maharaj-Kumar Victor N. Narayan

1915

W. 


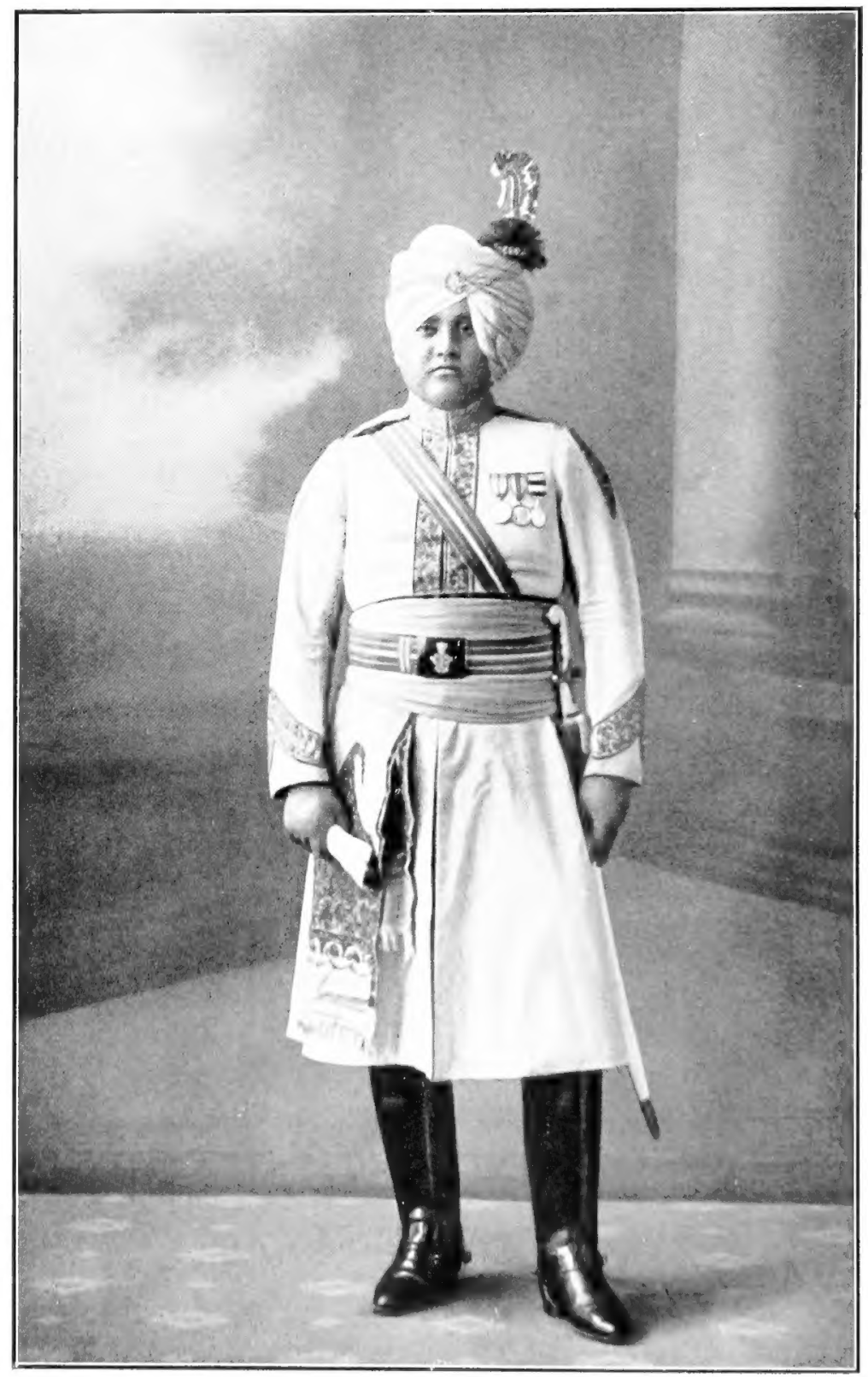

Muharil Kuma* Victur N. Naralan

of conoh Brhit 
To

\section{Maharaj-Kumar Victor N. Narayan}

\section{OF $\mathrm{COOCH}$ BEHAR,}

The first Indian Prince to go abroad to learn Scientific

Agriculture for the development of the resources of his country, these few pages are dedicated, as a token of esteem and regard, and in sweet memory of the happy days spent with

him in the United States, and the tobacco regions of Cuba. 


$$
\begin{gathered}
@ \\
S B=73 \\
I 4 M=3
\end{gathered}
$$

RRINTII BY N. MITKHERJER, B..., AT THE

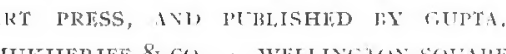

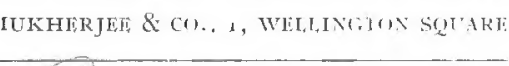
Ca 53479 


\section{INTRODUCTION.}

This short paper on tobacco was originally written by Mr. Majumdar for the tenth Session of the Indian Industrial Conference, held at Madras in the last week of December, I9I4; and was published without any illistrations by the Conference together with their other papers. Photos selected from out of a hundred taken by the writer and myself, together with a few others have been inserted.

Tobacco is a principal crop of Cooch Bchar; and with a vicw to introduce in the State scientific methods of curing as followed in other countries, under the instructions of my father His late Highness Maharaja Sir Nripendra Narayan Bhup Bahadur, I went to Cornell University, New York, where I specialised in agriculture for some time; and to Cuba, West Indies, where I obscrved the methods of the culture, curing, and manufacture of the famous Havana tobacco. Mr. Majumdar was deputed hy my father to accompany me in my tours, and to specialise in tobacco ; and later visited the different tobacco-growing centres in Macedonia and Asia Minor, where the best Turkish tobacco comcs from.

There are great possibilities for the improvement of Indian tobacco. The subject is a rast one, and cannot possibly be fully discussed in a small pamphlet. However, some of the fundamental principles of tobacco growing and curing have been concisely put down by the writer; and I trust these few pages will be of some help to persons interested in the crop.

India is essentially a farming country, but her agriculture is left entirely in the hands of the poor and the ignorant ; and there being no proper combination of capital, labour and skill, the rural masses, who form br far the largest part of the population, 
live from hand to mouth. It is no wonder, therefore, that there is a deep-rooted fceling among the young men lorking for a living, and for the well-to-do amongst our countrymen, secking for a good investment of their carital, that "agriculture does not pay. in India." 'There are a good many instances, however, of peoplc making money by horticulture, floriculture, kitchen-gardening, poultry and dairy farming in the ncighbourhood of big towns. Of course in the culture of ficld crops, the pulses, and cereals, where individual skill does not come much into play, and where there is no great scope for specialised knrwledge, the chances of making large profits are minimised. But the case is quite different in the production of such crops, as tobacco, tea, etc., which pass through various stages, and requirc expert and scientific handling before they are put on the market. He have quite a number of tea plantations, working successfully in India at the present time; and we had a good many indigo plantations a few decades ago. But there is no tobacco plantation worth its name in India, working with improved machinery, and on up-to-date scientific principles; although tobacco is one of our principal crops, and the annual outturn of tobacco in India is greater than that in any other country in the world, excitt the Inited States. Of course we cannot expect to make such fabulous profits by the growing and curing of tobacco in Inctia, as in the plantations of Simatra and the Vuelta Abajo regions of Cubil, hecause our soil and climatic conditions are not as favourable as in those islands. IBut still there are immense pussihilities, and it is high time that the attention of our cuterprising capitalists lex drawn to this much neglected crop of India, which plays quite at important part in the commmic condition of un country.

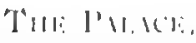

conch liehar, 1.51h Junt 10) 


\section{HOW TO IMPROVE THE TOBACCO CROP OF INDIA.}

India stands second among the tobacco-growing countries of the world as regards the quantity of the crop produced, the first in order of production being the United States of America. From this fact can be realised the great importance of tobacco in the agriculture of this country.

The writer, in order to study tobacco in its various phases of agriculture and manufacture, spent a few vears in some of the principal tobacco-growing countries, as the United States, Turkey, and Cuba ; and risited some tobacco factories in those places, besides a few in England, France, and Egypt. In this short paper will be dealt with, as far as space permits, some of the broad principles which have been followed with success in the improvement of the tobacco crop in those countries, especially the United States, and which are worth trying in India.

The tobacco industry has become highly specialised; and each kind of tobacco, whether grown for the manufacture of cigars or cigarettes, for smoking in pipes or for chewing purposes, needs special treatment regarding culture, curing, and preparation for the market before manufacture ; and requires different climatic conditions, soils, manures, and fertilizers to develop the respective properties in accordance with the respective 
trade requirements. From tobacco srown in $\mathrm{Cuba}$, which is an island in the West Indies, are manufactured the best cigars in the world. 'These are known as Havana cigars, Hatrana being the name of the capital of Cuba, where the tobacco factories of the island are located. The best cigarettes of the world, manufactured in Exypt, and known as Egyptian cigarettes, are to a great extent prepared from tobacco grown in Turkey. It may be remarked here that no tobacco is yrown in Figrpt ; and the reason why Turkish tobacco is manufactured so largely in Egypt is because, in the first place, the Turkish Imperial Regie has the sole monopoly of manufacturing tobacco in Turker, and no private companies are allowed to establish tobacco factories there ; and secondly because Egypt is the most convenient place for the manufacturers of Turkish tobacco, on account of the proximity of Exypt to Turker, and the dryness of the climate, which is favourable for its manufacture. In the United sitates different varieties of tobacco are grown in different parts ; and though the quality, except in some particular localities, is not as good as that of Cuba or Turkey, where to the soils and climatic conditions mainly are to be attributed the superior qualities of tobacco, the I'nited States follows the most scientific and up-to-date methods of agriculture, and is undoubtedly the leading tobiconsrowing country in the world.

Though tobacco is one of the principal crops of India, the quality turned out is rather inferior, and the market price of the product is considerably lower than that of most of the other combrics. The improvement, therefore, of the crope on the lines stcecsstully folloned in other countries, is of vital importance to the comomic condition of this comntry The ohject of this paper is 


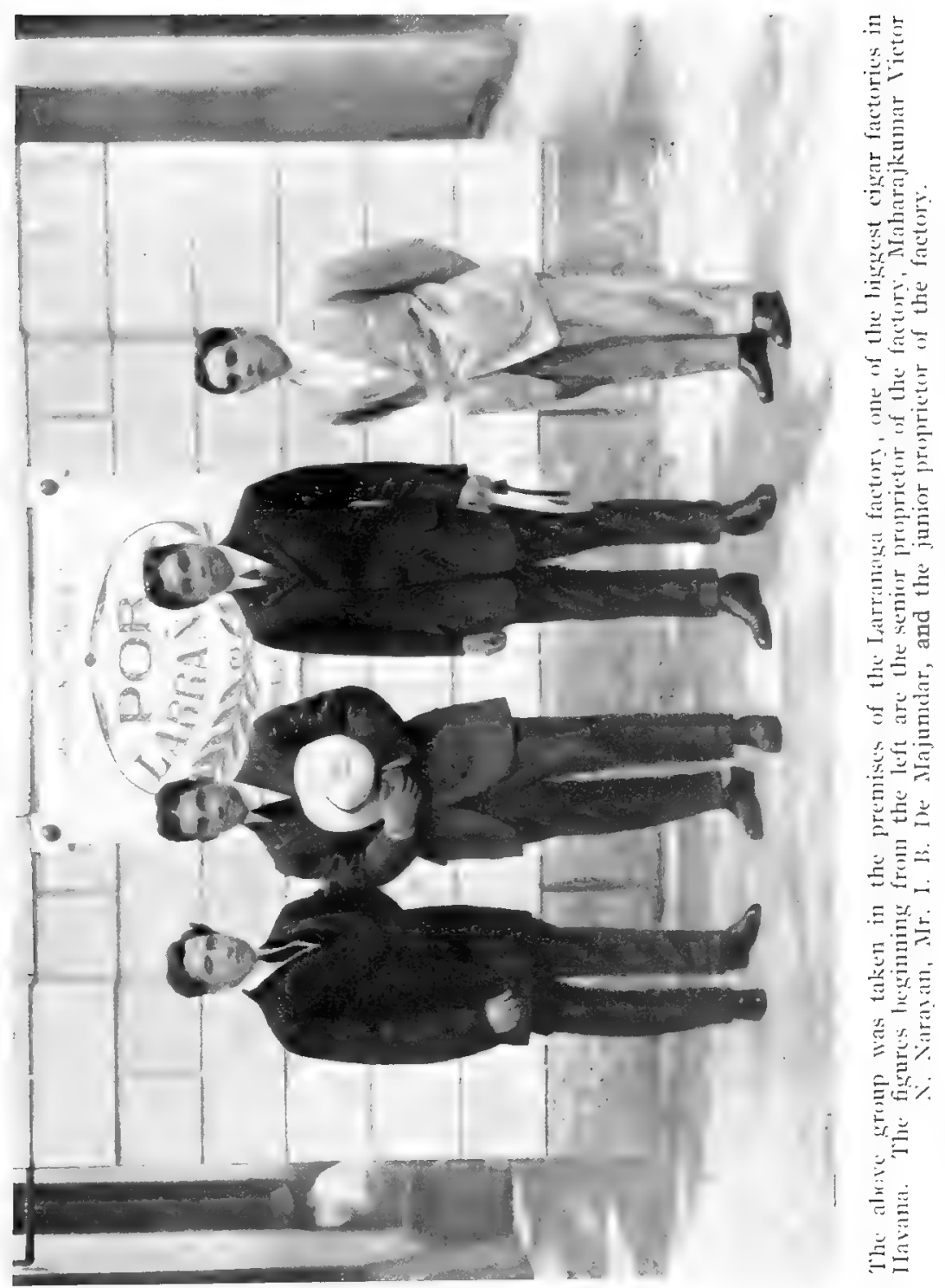


to show some of the aspects in which the improvement of the crop may be effected in India. The principal ones may be classified thus :-

I. Improvement of the crop by breeding and selection.

II. Adoption of up-to-date methods of curing.

III. Introduction of superior varieties from other countries.

We shall deal with these points one by one. The duty on imported tobacco is greatly in favour of the development of the indigenous crop and the culture of foreign varieties. The great industrial crisis through which we are passing on account of the war has also given a fresh impetus to the development of our natire resources, and so the present moment is quite opportune for enterprising capitalists to paly their attention to the improvement of the Indian tobacco. The writer of these pages hopes that his suggestions may be of some use to risitors interested in tobacco-growing, at the tenth Indian Industrial Conference at Madras, which by the way is a principal tobacco centre in India.

\section{IMPROVEMENT BY BREEDING AND SELECTION}

There is considerable scope for improrement in the rield and quality of tobaco as well as of other crops in India by breeding and selection. As there are sereral distinet types of tobacen, which have different trakd requirements, it is essemtially necessary for a tobacon

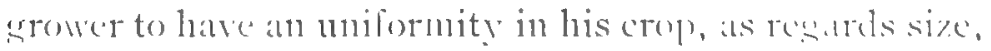
shape, ete., of the leaves ; ind this camnot be coflected if the purity of the sects commot be preserved. "The" individual plant is the result of two foress:-emvironment (climate, soil, fertilise, culture, ete.) and heredity 
(parents, grand-parents, etc.). The improvement and increased yield of a crop by modification of environment, although a necessary process to successful agriculture, can only be accomplished at an expense, more or less considerable. Heredity, howerer, is a silent force, which acts without expense." Breeding and selection, therefore, are just as important in the vegetable as in the animal kingdom. This phase of agriculture is not

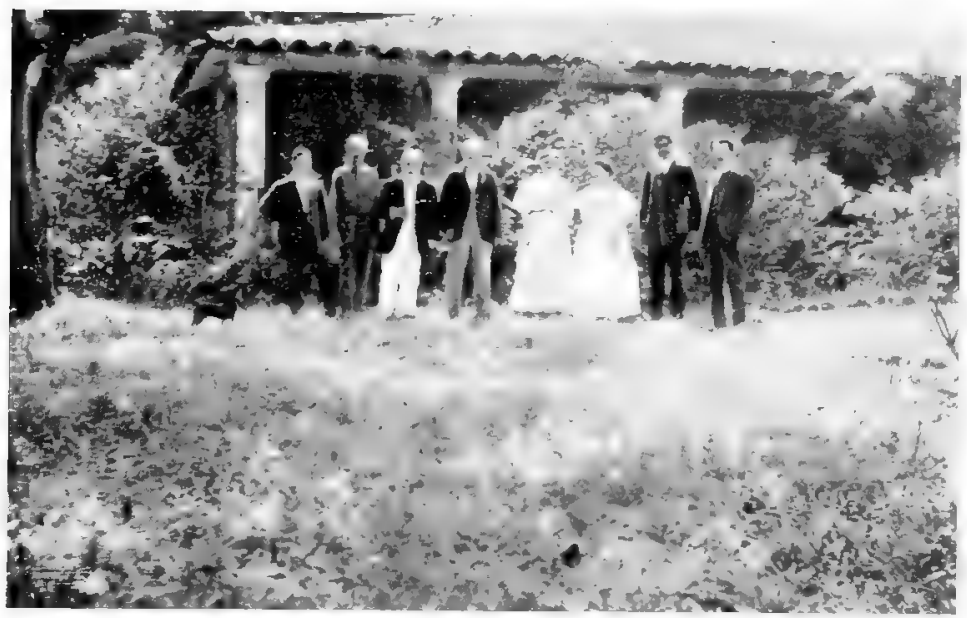

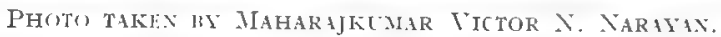

Residence of Mr. Holnes, an Anerican tobacw planter in I'inot del Rio, Cuba. The figures from the left are Mr. Holnes (Jr.), a farm Assistant, the Mayor of Pinor del Rio, Mr. Holmes (Sr.), Miss Holnes, Mrs. Holmes, It. I. B. De Majundar, and the secretary to the Govenor of Pinor del Rio.

as well understood by the Indian cultirators as by their fellow-workers in Europe and America. In the I'nited States, seeds of tobacco as well as those of other crops are properly selected by seed merchants as well as by the Department of Agriculture, the latter sending the seeds free to the farmers who apply for them. The methods followed are briefly described here. 
The tobacco plant is naturally self-fertile, but crossfertilization is often effected among the plants by many species of bees and insects, which carry pollen from flowr to flower. This condition results in a large proportion of the crop being hybrid plants in the following vear, and leads to great variability. In some species of plants cross-fertilization is absolutely essential to seed production. In other species it produces more and better seeds than self-fertilization. But tobacco belongs to still another class of plants which are abundantly self-fertile, and in which self-fertilization has been proved by experiment to be more effective for seed production than crossfertilization.

The I'nited States Department of Agriculture resort to bagging the flower-heads of the selected plants to prevent cross-fertilization, and thus to secure uniformity among the leares. The characters which are given the closest attention in selecting the seed-plants are the general habit of growth or type of plant:- the number, shape, size, and uniformity of leares, the distance between the leaves, time and uniformity of ripening, heiwht of plants, number of suckers, uniformity of colour of leaves, and freedom from diseases. It is of vital importance to select plants with a larse number of marketable leales, in order to secure an increased vield. The plants on which the lower leaves are over-ripe before those near the top begin to mature should be discarded. seceds from plants shewing a few suckers will produce a small number of smekes the bollowing year, and those shewing a larse number will transmit this nndesirable tendemey to the progemy, provided othere things are equal. After the selection of seced-platuts hats best made in the field, the flowering part of the plant is concred with an 
ordinary paper bag, which is a very simple, cheap, and at the same time effective method of protecting the flower from cross-pollination and injurious insects. For this purpose the $\mathrm{r}_{2}$ th size bags are found admirably suited, as they give sufficient room for the proper development of the flowerhead of an ordinary tobacco plant, and at the same time they are not heary enough to injure the pla:t in any way. The bag with a roof-shaped bottom is

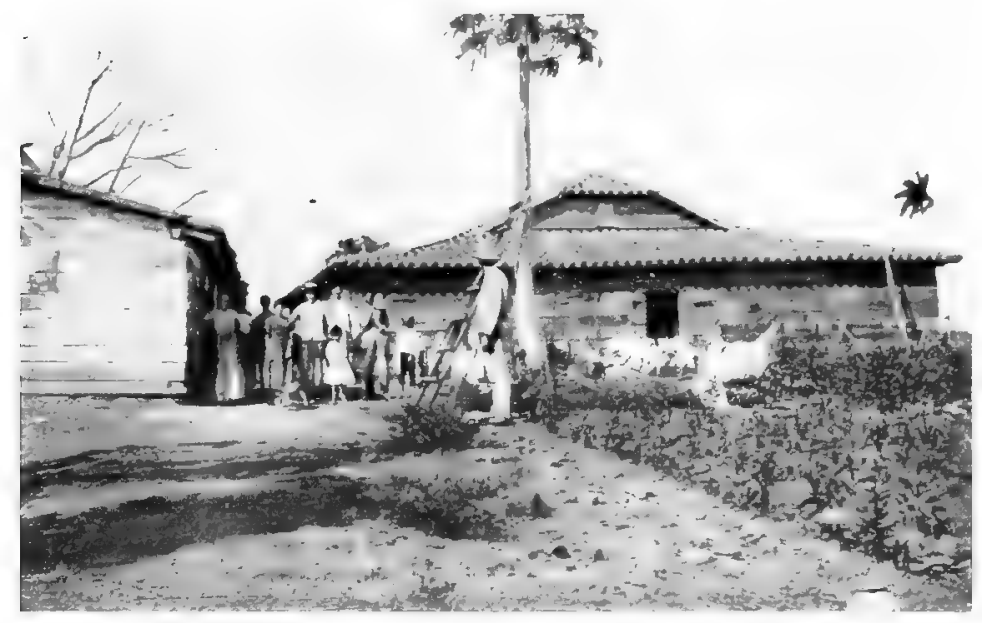

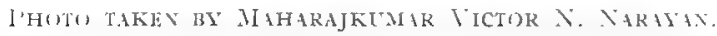

House of a tobacco grower who is a tenant in Sinor suarez's plantation in Pnerto de Golpe, Cuba.

better than the square bottom shape because it sheds the rain better. The proper time for placing the bag orer the plant is just before the earliest flowers begin to open. After five or six days the bag should be temporarily remored, and all suckers broken off. It should be replaced at once, and elevated a little above its original position, in order to give sufficient room for the derelop- 
ment of the seedhead. This operation should be repeated once a week for two or three weeks. When most of the seed capsules are turned brown indicating maturity, it is desirable to remove the bag, and cut off all the late flowers, flower-heads, and poorly dereloped capsules, leaving only the larsest and best to mature seed. The bag should be replaced after this is done, and allowed to remain until the stalks have been cut and dried out. During the process of drying, the bags serve as a protection, and catch any seeds which may fall out.

It has been found that heary tobacco seeds produce like other arricultural seeds more rigorous and productive plants than lighter seeds. This is because the heary seed has a perfect embryo or plantlet in it and a large supply of arailable plant-food. Notwithstanding the exceedingly minute size of tobacco seed, the writer has seen that in the I nited States Department of A:riculture at V'ashington, D.C., a perfect separation of the tobacco seed into light and heary grades is effected by means of a separator consisting of a glass tube one inch in diameter and fire feet long, and at liss receptacle for holding the seed, having the diameter of the lon: glass tube. The receptacle is so arranged with a finely woren wire screen in the bottom as to hold the seed in the receptacle, and at the sane time fully admit a current of air directly into the seed. The top of the recepticle is fitted with a coupling into which the long whas tube can be set and held in place. The current of air is anerated by a common foot-bellows, and resulated with a ralle inserted into the receptatele, and comected to the bellows with a rubber tube. The seced to be segranted is promed into

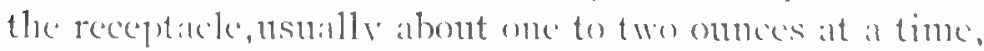
the elass tube set in place, and a cmrrent of air pumped 
into the seed. The lightest seeds and the chaff are first blown out of the tube, and next the small seeds. The materials necessary for constructing this kind of tobaccoseed-separator can be obtained in any chemical house.

\section{ADOPTION OF UP-TO-DATE METHODS OF CURING}

If a sample of tobacco taken from the field at the usual time of harresting were dried out rapidy on an oven, and manufactured into appropriate forms for smok-

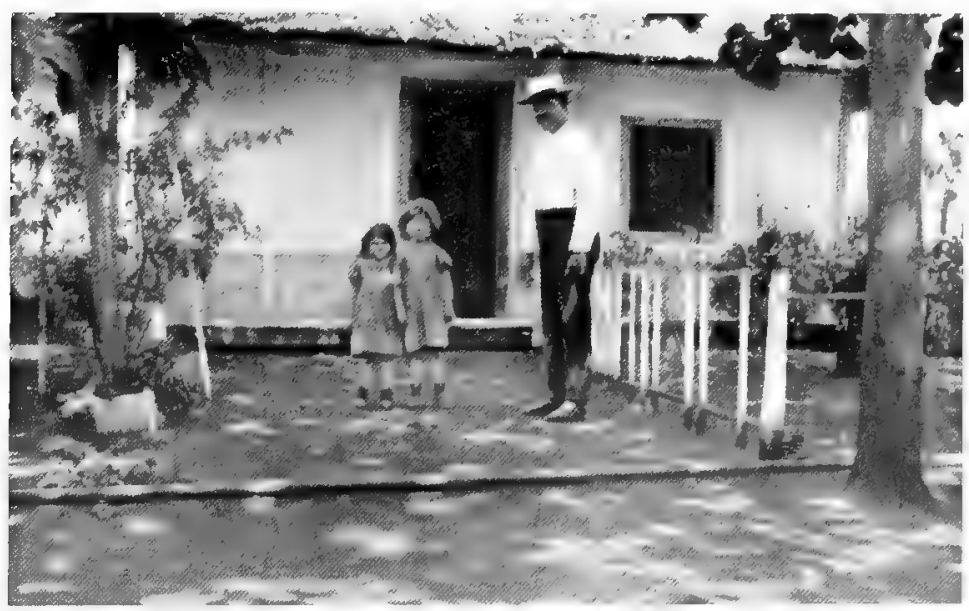

Phóo taken by Maharajkumar Victol $N$. Nakayax.

A cottage for labourers in Mr. Luis Marx's plantation, Alquizar, Cuhá.

ing or chewing, it would be found to retain a green colour and a rough surface; and when smoked would burn badly, leaving a black ash, giving off a tarry ill smelling smoke, and imparting a bitter burning flavour. Whereas a properly cured tobacco has a brown or yellow colour, a silky texture, burns with a smoke of delightful aroma, holds fire well, vields a white or light gray ash, and has 
no sharp or unpleasint taste. In other words, it is evident that marked chemical clianges have occurred, resulting in the destruction of substances which in burninc give off undesirable compounds, and the formation of other materials that give off in burning substances of pleasant smell and taste. ( )n the other hand, if the leaf be killed by chloroform or frost, the changes ordinarily observed to result from curing do not occur. Curing is partly a life process, and is to some extent due tro the activity of the cells of the leaf.

\section{The Ripening of Tobacco}

Soon after the leares of the tobacco plant reach maturity, they undergo marked changes in colour and other properties. The young growing leaf has an intense green colour, shewing that it is quite rich in nitrogenous constituents, which go to make up the living or rital part of the leaf, and which are active in building up the food supply of the plant. The object of topping (remoral of the flower head) and suckering (removal of the suckers or offshoots) as practised by the tobacco-growers is that the food built up by the leares may accumulate in the leaves themselves, instead of beins carried awar to the seedhead and the offshoots. The result is that both the size and thickness of the leaf are increased. The reserved food supply of the mature leat is deposited in the leaf tissue in the form of starch sramules, while the sreen colouring matters are cissolved and carried to the vounsere, srowing parts. At this stage there is at decided change in the colour of the leaf. Morcener, the accomulation of the starch grantules in the lat callses it to beome brittle, so that it smaps when folded between the fingers, another chatateristic sien of ripeness. 
Now the replacement of the complex nitrogenous constituents, including the green colouring matter, by the starchy ingredients has a most important effect on the colour, flavour, elasticity, and finish of the leaf. Indeed, much of the success in curing tobacco depends on harvesting it just at the right time, when it is neither

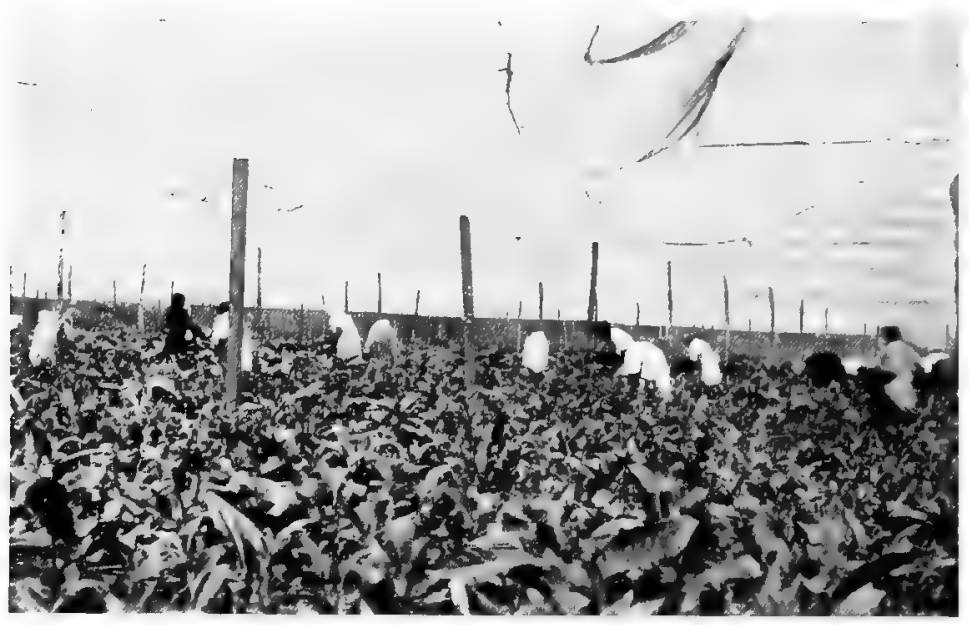

['HOTO TAKEN BY MAHARAJKUMAR VICTOR N. NARAYAN.

Fenule lahourers harvesting tobacos leaves in Mr. Marx's plantation. Tobace grown under shelter of cheese cloth. Mr. Marx's plantation is supposed to be the richest and the best equipped in Cuba.

too ripe nor too green. Thus, in the case of cigar* tobacco, the brightest, clearest, brown colour is obtained

"If a high class cigar be unrolled, it will be found that three kinds of leaves have been used in preparing it. The innermost tobacco in the cigar is called the 'filler'; the next leaf used is the 'binder', to keep the filler in the form or shape of a cigar : and the finishing or outside leaf is called the 'wrapper' The filler leaf is generally selected for its taste, swetnesi. and strength, and the wrapper for its light colour and fineness in appearance. The binder and wrapper leaves are usually neutral in taste, etc. It is not necessary that they should contribute to the flavour, aroma and strength of the cigar like the filler leaf, but they nust not have any undesirable qualities rendering the cigar worthless. The Cuban tobacco rields the hest fillers, and the Sumatra tobacco the best wrappers. 
when the leares are harrsted just before they would be called fully ripe. A green leaf after curing will be tough and leatlery, while an over ripe one will be "strawy" and lifeless to the touch. Finally, since the materials which develop the flavour and arona are derived from the green nitrogenous compounds, the fully ripe leaf will be deficient in those qualities, while the green leaf will possess them much more fully dereloped. It is evident, then, that the lower, fully matured leaves of the plant when moderately ripe will be best suited for the production of cigat wrappers, bright in colour, and having the necessary elasticity, but neutral in flavour; while the upper leaves harvested before they have fully matured will give the best fillers having the required flavour and aroma, but being much darker in colour than the wrappers. In curing the "vellow tobacco" for the manufacture of cigarettes, it is necessitry that the leaf be fully ripe, for the content of the green colouring matter must be reduced to the minimum, consistent with the required toughness, in order to obtain the cured leaf free from green or brown discoloration.

\section{Different methods of Harvesting, Hanging and Curing}

The harvesting, hanging, and curing operations vilry widely for different types of tobicco. They also vary in different countries for the same trpe of tohacco. A summary is siren below of the different practices, in

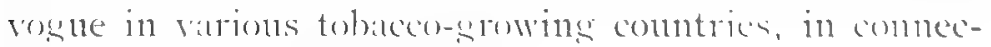
tion with these operations.

HARVIISTR: :

A. Witlothestalk.

I. Iiv cutting ofl the whole st.lls. 
2. By cutting off two or three leaves with the corresponding portion of the stalk.

B. Leaving out the stalk.

I. Leaves taken singly as they ripen.

2. All the leaves on the stalk taken at one time. HANGiNG:

A. When harrested with the whole stalk.

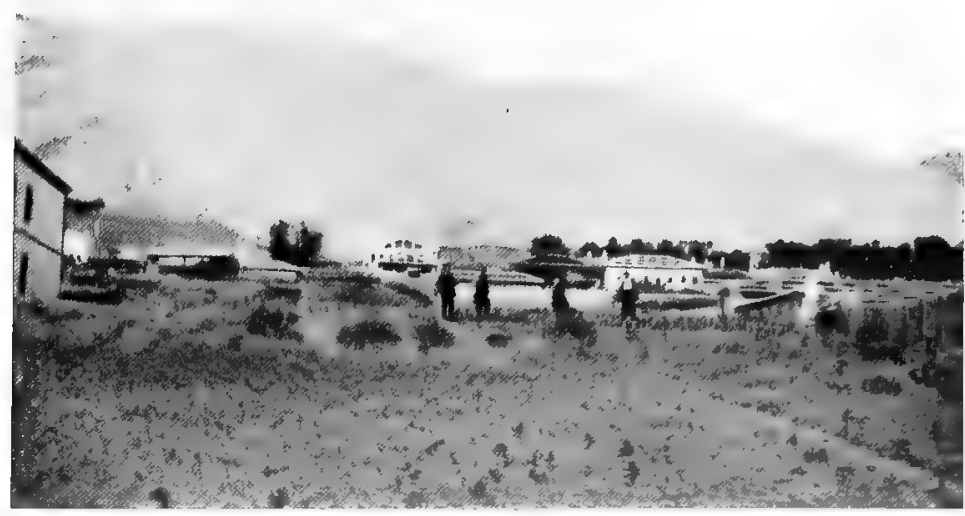

PHOTU TAKTEN BY MIR. I. B. DF M IJUMDAR.

Kiretcheli (Yaka), a village near Xanthi, Macedonia. Tobacco grown in these lands fetch the highest prices in 'Turkey.

I. Splitting the stalk and hanging on the laths or sticks, butts up.

2. Hanging over laths by means of the rib.

3. Tring to laths by means of twine.

4. Spearing upon laths. (A detachable iron spearhead is fitted at the end of a lath by means of which the stalk of the plant is pierced. 
Four to six plants are placed on a lath four feet long.)

5. Hanging upon laths by means of wire or nailhooks.

B. When harvested with sections of the stalk.

I. Hanging over the laths.

2. Stringing on cords.

C. When the leares are harrested alone, without the stalks.

I. Tying in pairs and hanging over the laths.

2. Stitching upon strings.

3. Spearing upon wires or nails on laths.

4. Spearing upon metal rods. (Metal rods six to eight feet long, and strong enough to bear the weight of the leaves without bending, are used. They are pointed at one end or tipped with a metal knife, by means of which the midrib of the leaf may be pierced near the base. The leares are speared back to back and face to face, and placed one or

L'URINT: two inches apart.)

A. Sun curing. (Tobacco is exposed to the he it of the sun, but protected from rain by temporary shelters. Tobacco in Turkey is at first sun-cured for a few weeks, and then air-cured inside cottages to finish the curing.)

B. Air-curing or Barn-curing.

(a) Wilting:

I. Iscil wilted before being taken from the field.

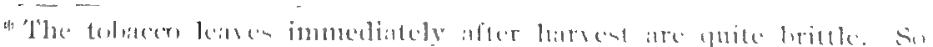

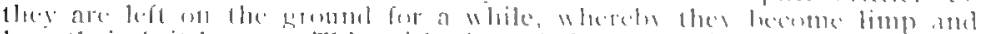

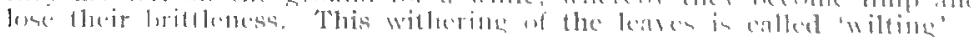




\section{I5}

2. Leaf partly sun-cured before being taken from the ficld.

3. Leaf brought to the curing barn immediately after harvest.

(b) Preliminary sweating:.

I. Leaf slightly sweated before hanging.

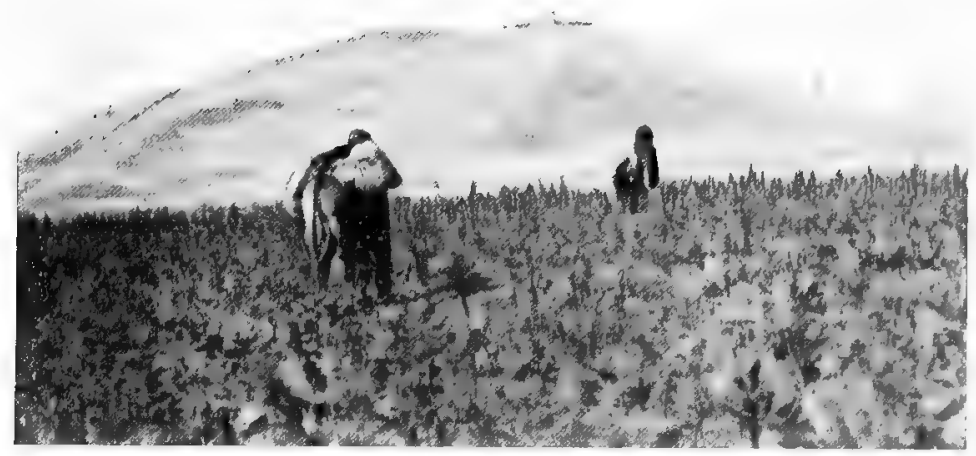

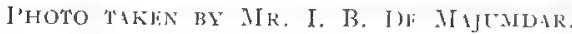

Harvesting of tobacco leates at Philippi, Macedonia. It "Iill be obuerul thit leaves of Turkish tolacco are very small in size, the lengths of different types varying from $2^{1 /}$ to $S$ inches.

2. Leaf riolently sweated before hanging.

3. Leaf hung without previous sweating. (c) After-sweatiny or Fermentation.

* Leaves are collected in bundles and packed into nıderate sized heajk to sweat. Matting is placed over the heaps, and a gradual rise of temperature begins. The increase in trmperature is due to certain processes which are taking place within the leaves, whereby their nore complex contents become broken down into simpler ones, with an evolution of heat and water. The water thus given off is in vapour form, but it condenses again on the cooler matting covering, and it is the presence of this water which gives rise to the idea of the heaps sweating. Care is needed at this time to prevent overheating, for if the temperature rises unduly, the leaves get darkened in colour. 
c. Fire-curing.

(a) Wilting. Variations the same as air-curing.

(b) Time of using artificial heat.

I. Fire used only during very moist weather, to prevent pole-burn.

2. Fire used only after the leaves are coloured by air-curing.

3. Fire used to start a sweat, then drawn, and again used, after the desired colour is attained by air-curing.

4. Artificial heat applied continuously

(c) Method of applying heat.

I. By open fires.

2. By stores and flues

(d) Kind of fuel.

I. Coal.

2. Wood.

Harvesting. - About the two kinds of harrestin!. riz: $(a)$ cutting off with the stalk, and (b) gathering the leaves singly, there has been much discussion from a practical as well as from a scientific stand-point. Fich has its advantages and disadvantages. The scoond method is followed in the case of the Turkish, the C'uban, and other high priced varieties of Tobacco.

The advantige of the first method is that it silves labour, and is less expensive than the other. The chict disadvantage is that all the keanes on the plant do not ripen at the same time, so that the tobsecen hats to be harrested at such a time as will give the greatest mumber of the best leates at the propert stage of ripeness, thus necessitating a comsiderable salerifice in buth bottom and 
top leares, since the former are over-ripe, and the latter immature.

The advantages of the second method are :-

(I) The planter can begin to house his crop from two to four weeks earlier, as the bottom leares which ripen first can be taken off and cured as soon as they are ripe.

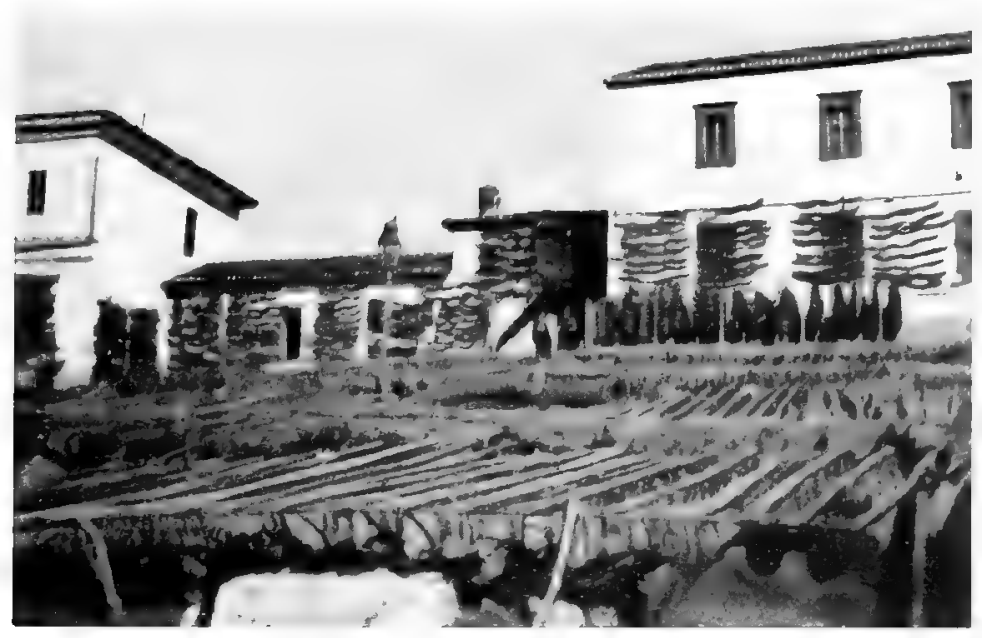

PHUTU TAKEN BY MR. I. B. DE MUTMOAR.

Leaves in strings hung for suncuring on the walls of the building, and on scaffolds in the courtyard of one of the plantations (in Nacedonia) of Hazi Saccara, a rich tobacco planter of Turkey. The leaves are covered with mats (which are shewn rclled up in the photo) in case of rains.

(2) As the lower leares are pulled off those left on the stalk ripen more rapidly, which enables the planter to get in his whole crop earlier in the season.

(3) The tobacco can be cured in a much smaller space. 
(4) It is possible to harrest all the tobacco leares at the right stage of maturity and so the tobacco can be cured with sreater uniformity than when the lealles are harvested with the stalk.

(5) In cases where fuel is required a less quantity will be necessary, and the risk of setting fire to the harn will be greatly lessened.

(6) Although the handling of leaves separately entails more labour than harresting with the whole stalk, ret the sreit part of it is of such a nature that it can be profitably done by children, and at rarious times durin: the season.

Besides the questions of expense, labour, space, etc., the two processes also give rise to difference in the character of the cured product. The leares and the stalks remain alive after harvesting as long as they retain sufficient moisture, by means of the reserve food supply which has been stored up. The cuter edges of the leaf are first killed by loss of moisture, and the unused portion of the food supply is withdraw towards the midrib, which is the last part of the leaf to die. When the leares are picked from the stalk, of course this transfer of the food materials can wet no further than the midrib of the leaf ; but when the leaf remains attached to the stalk the ford materials pass into the stalk to keep this alive. () account of the watce contaned in the stalk, which yradually passes inte the leaf for replace that lost by a d aporation, the leaf also under these conditions memains alive for a much longer periogl than when separated from the stalk, and itself uses up more of its accommlated forod, 
so that the leares cured under these conditions are considerably lighter than those cured after being separated from the stalk. It has been found by experiment that picked leaves are about I I per cent. heavier after curing than those cured on the stalk.

Space will not permit a full discussion of the various systems of curing. As cigars and cigarettes are manu-

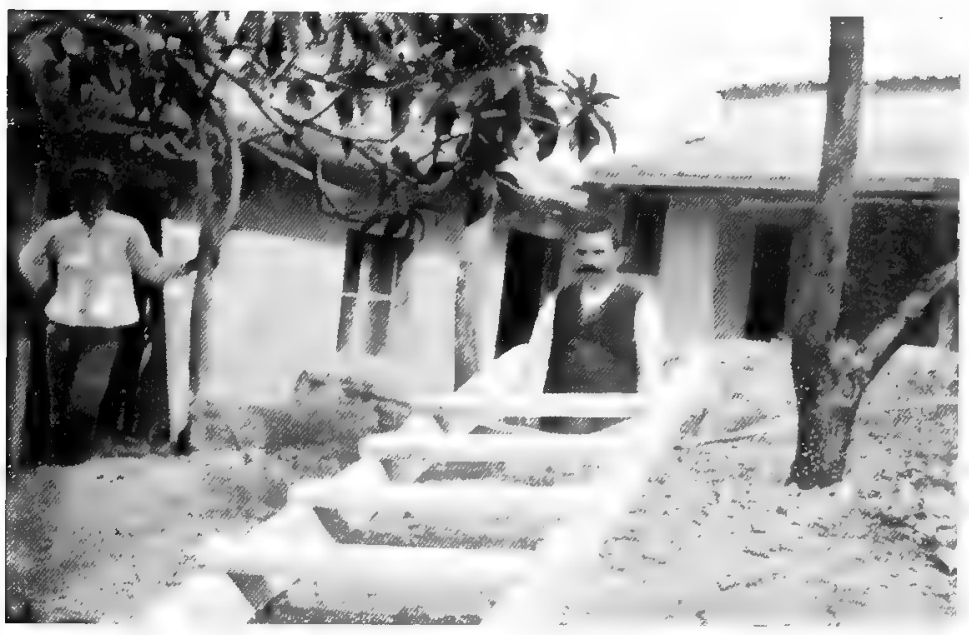

PHOLO TIKIN BY Mr. T. B. DE MiJUMdid.

A labourer just entering the subterranean pit where tobacco is kept after curing in order that it may get soft by moisture before it is sorted; as tobacco in a dry condition is brittle and likely to get injured at the time of handling. "The farm of Mr. Newhall (a Scotch planter) in Smyrna.

factured in India to a large extent, this paper will, therefore, be confined to the principles* which are observed in the curing of cigar tobacco, and in the curing of the

* In the preparation of this part of the paper, it is gratefully acknowledged that free use has been made of "Principles and Practical Methods of Curing Tobacco", by Dr. W. WT. Garner of the United States Department of Agriculture, in whose laboratory the writer most profitably spent a number of days. 
"yellow" tobacco which is largely used for the manufacture of cigarettes: (r) Air-curing is followed for the former, and (2) Flue-curing for the latter kind of tobacco.

\section{Air-curing}

Tobacco used for the manufacture of cigars is generally air-cured, artificial heat being used only during very wet weather. The curing is controlled simply by opening or closing the rentilators as occasion demands. In considering the changes taking place in the leaf during the curing process, this may be divided into two periods, during the first of which the leaf remains alive, while in the second the changes which occur have no connection with its life activities.

The principal changts taking place in the first stinte of curing are due directly to the activities of the living cells, while they are passing through a period of yradual starvation ; hence the conditions should be such ats are most farourable to these ativities. These cells are killed by bruising, so that it is important to aroid injurr in this wy in the harresting as far as possible. Agrin, these cells are killed by excessively low or high temperatures, and by the rapid loss of water. The life activities of the tobacco plant pratically cease at tempreratures below f " F, while they increase as the temprerature rises, until at about I $25^{\prime \prime} \mathrm{I}^{*}$ the living cells are rapidly killed. 'These activities are also ereatly lessented

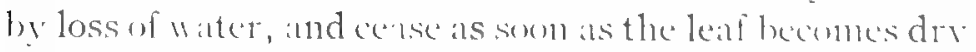
In pratice, the most fal ourable temperatures for curims

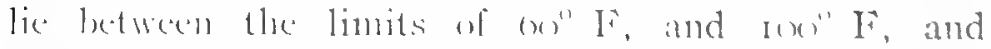
the relative humidity slomld be abunt is per econt. Inder lowe conditions the ked will stoddnally lose its 
water, but will never be too dry ; and the curing will proceed smoothly. If the humidity becomes much higher, pole-sweat* will derelop on the leares most advanced in the curing ; while if the humidity falls much below this figure, the leaf will dry out too rapidly.

We have seen that the ripe leaf is very rich in starch. One of the important changes in the curing is the disappearance of this starch, which is consumed by the

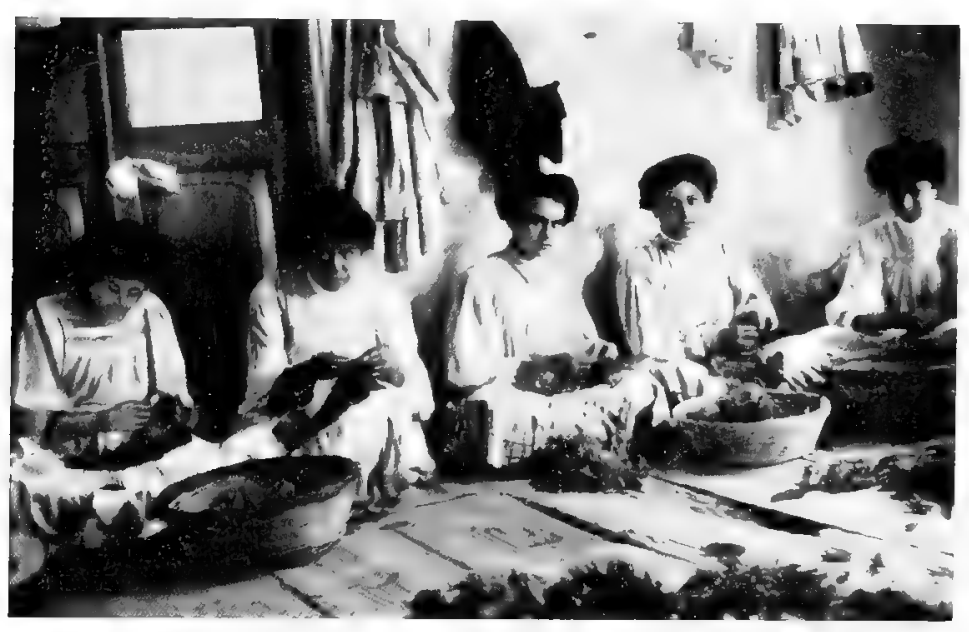

PHOTO TAKEN BY MIR. I. B. DF M MJMMIIR.

Armenian and Jewish girls sorting trhaces in Mr. Newhall's farm.

living portion of the leaf itself. Now if the leaf is killed by bruising, by excessive heat, or by too rapid drving out, there is no means of remoring this starch, and the tobacco is harsh, lifeless, and "strawy". Along with the

\footnotetext{
*This is the chief tobacco-disease and occurs the world over, where tobacco is used without the use of heat. It first appears as dark spots near the midrib or vein, and then spreads rapidly discolouring and rotting the whole leaf.
} 
chinges in composition, the green colour is replaced by a lemon yellow. This change from green to yellow takes place in all tobacco whatever the method of curing may be, if it is properly conducted. The green colouring matter or chlorophyl of the tobacco leaf, is found in all green plants in very similar, but not identical forms. During the period in which the leaf issue is undergoing starvation, the green colouring matter is more or less completely changed into colourless substances; and the appearance of the rellow colour marks the approaching death of the leaf. It must not be thought that the yellow colouring matter is formed during the curing process, directly from the green colouring material. . The yellow colouring matter is contained in the green leaf before it is harrested, and also after it has turned brown. The yellow is simply obscured in these cases by the more intense wreen or brown.

In building a good barn for the air-curing of tobacco, the two principal considerations to be kept in mind are to construct it as nearly air-tiglit as possible, and at the same time to provide an efficient system of ventilation ; for in the absence of any method of supplying artificial heat, these constitute the only means of controllin: curing conditions. The fundamental principle to be kept in mind during the first stage of the curing is to aroid tom rapid drying out of the leaf. Many moners, in their anxicty to alvoid damage from pole-sillent, calused by exressive moisture, injure their tobacen very seriomsly hy soing to the other extreme of drying ont the leaf sor rilpridly as not to allow sufficient time for the chanses to take plike, which are essential to genel suring, dependent on the life activities of the leaf, and are, therefore, stoppled

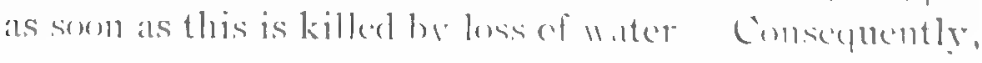


if the outside air is very dry, the barn should be kept closed during the day, and opened up at night. The object is to keep the moisture of the air in the barn quite high until the important changes in composition have taken place, as shewn by the change in the colour of the leaf from green to vellow. Of course, if the outside air is quite humid, the barn should be kept open during the day.

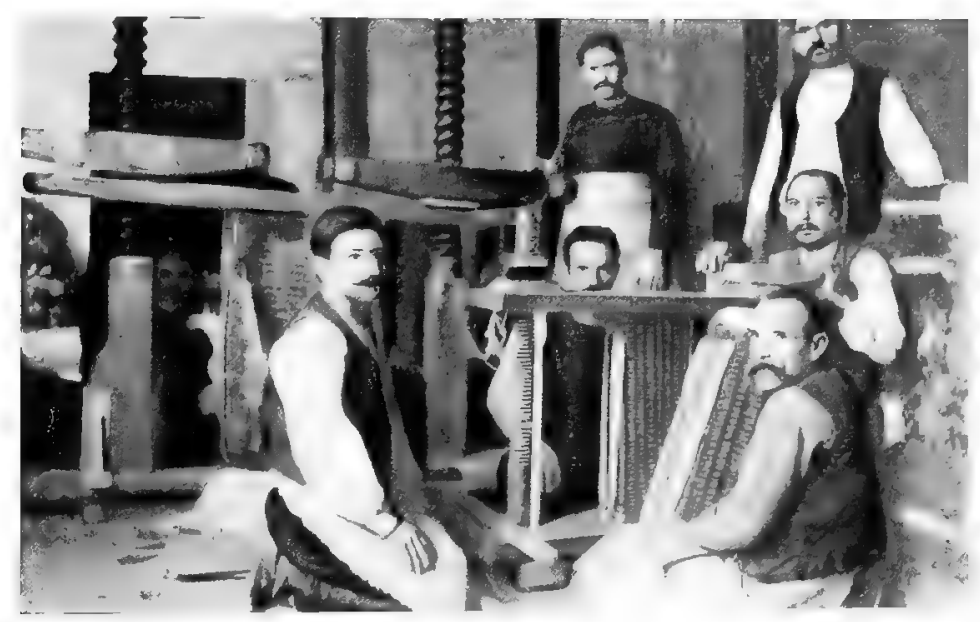

I'HOTO TAKFX BY IIK. I. B. DE MAJUMDAR.

Itand press for baling tobacco. The buildings of the Turkish Regie, Nanthi, Macedonia.

The full derelcpment of the rellow colour marks the end of the first period of curing. During the second stage the changes consist mainly in the further breaking up of the products formed in the first stage of the curing, and the derelopment of the brown colour. Here again it must be understood that brown colouring matters are not derived from the yellow, nor are they derived directly 
from the green colouring material. They are formed by a process of oxidation which does not take plite till the cells of the leaf are dead. As soon, therefore, as portions of the leaf die, they at once besin to turn brown, provided sufficient moisture is present. The two essentials for the development of the brown colour are a supply of oxysen, which is obtained from the air, and a sufficient anount of moisture. This development of the brown colour, which is butun in the second stase of curing, is always completed in the fermentation of the trobicio ; and the chief danger as reards the curing is that the development will proceed too far becanse of excesive moisture, causing the leaf to cure too dark.

As regards quantity, the most important chanse in the curing is the loss of water. The tobacco leaf normally loses atwut 55 per cent. of its : 2 reen weight in the curing, and by far the sreater portion of this loss in water. To cure tobacco sucessfully, this rast amount of witter must be remowed under such conditions and at such a rate as will hest allow the other important changes to take place. In the second stane of the curing, whe? the leaf begins to turn brown, the relative humidity may

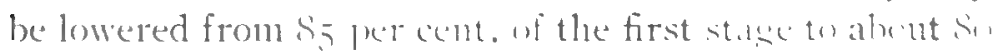

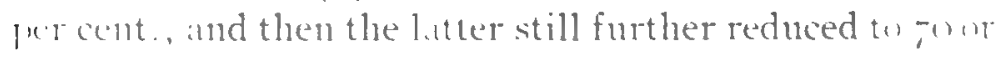
1,5 jecent., wntil the stems are dry. If the humidity remains wer hish at this st.lece for any considerable period, pole-sweat will surely decelop. This is whe he

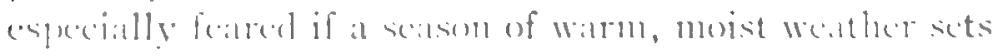
in, and mal semen rencler the entire contents of the barn pratedically worthless. The only remedy lies in the use

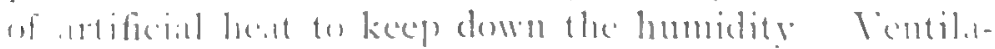

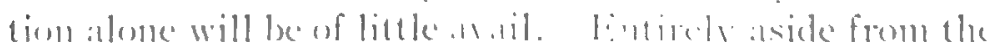

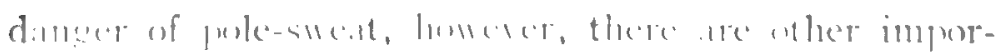


tant reasons why the humidity of the barn should be reduced as soon as the brown colour begins to develop.

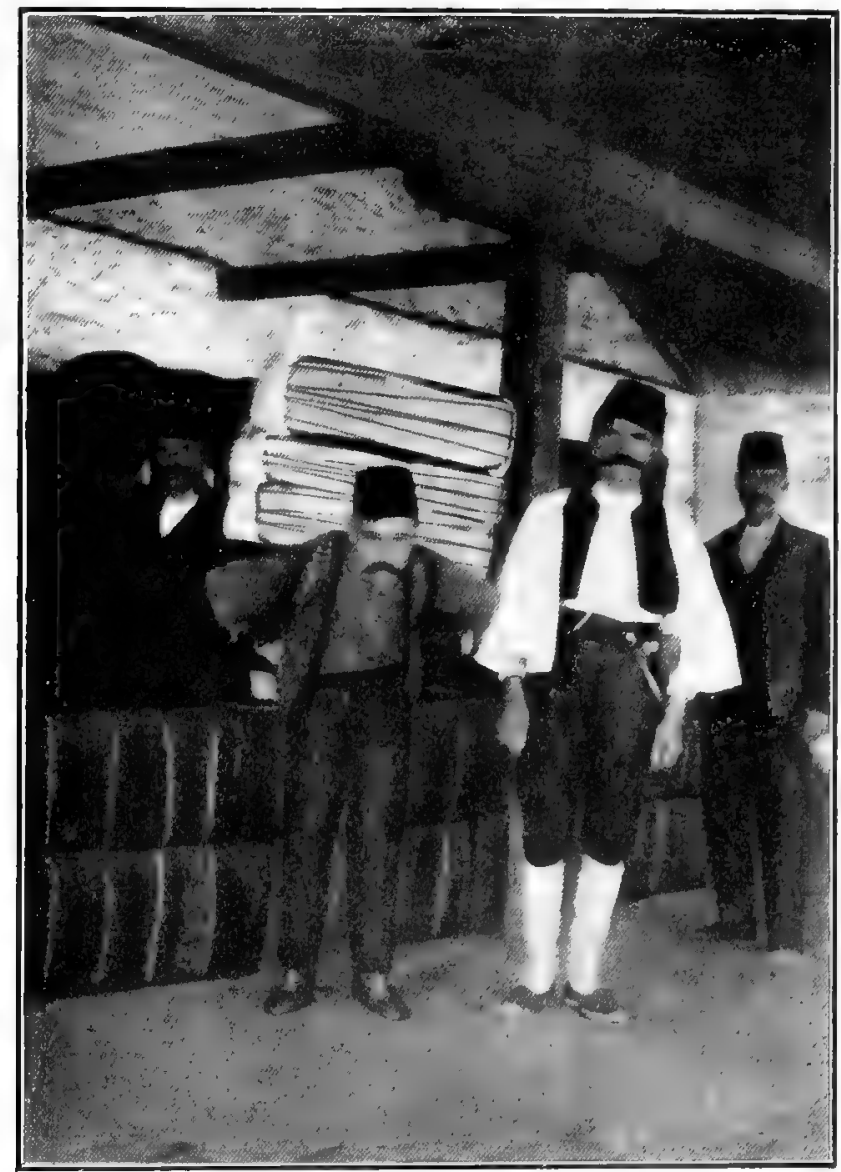

Photo taken by Mir. I. B. De Majumdar.

Turkish labourers carrying bales of tobacco on their backs, a common sight in the streets of Cavalla, Macedonia.

The leaf dies at this stage, and the further changes in composition and properties are such as can be better con- 
trolled in the sweat-room (where the ventilation, temperatue, and humidity can be easily regulated), than in the curing shed. At the present time the demand is for bright colour in wripuke leaf, and the longer the second stisge of the cure is protracted by a relatively hich humidity the darker will the leaf be. The rational method of procedure, therefore, is to maintain a high humidity during the first stage of the cure, and then, as soon as the colour has developed, to dry out the leaf comparatively rapidly

After the cure is finished the leaves are tied into bundles, and arranged in bulks on an elevated platform. The bulks are corered with oil-cloth or other suitable material to prevent the leares from drying ont. They must be carefully watched to prevent their becoming heated, which is mactically liable to occur if the leaf is paked down too moist. If herting does occur, the piles must be torn down, and rebuilt after the bundles have been shaken int.

licfore the laif is realy for the manufacturer, it must underen it proces of fermentation, commonly

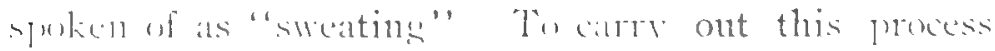
strcessfully requires a thornuhly equipped plant with adequate facilities for controlling rentilation, temperatture, and humidity, so that as at rule the anomers sell their leaf in the bundle to the dealers, whe make a husiness of carroing on the fermentation on al lares side. The

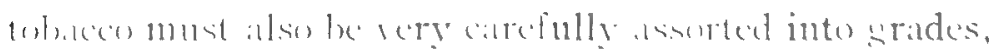
but the deder ecencrally prefers to do this himself in

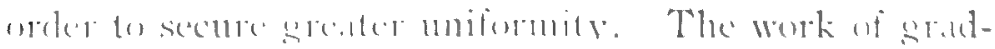

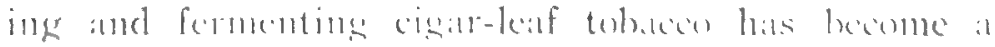
hishle spectidised industre, quite distinct from the cur- 
ing process, properly speaking, and so does not require further consideration in this short paper.

\section{Flue-curing}

For this method of curing the barn must be provided with a system of large pipes or flues, through which the heated air is passed throughout the curing period. The smoke does not come in contact with the tobacco, and the

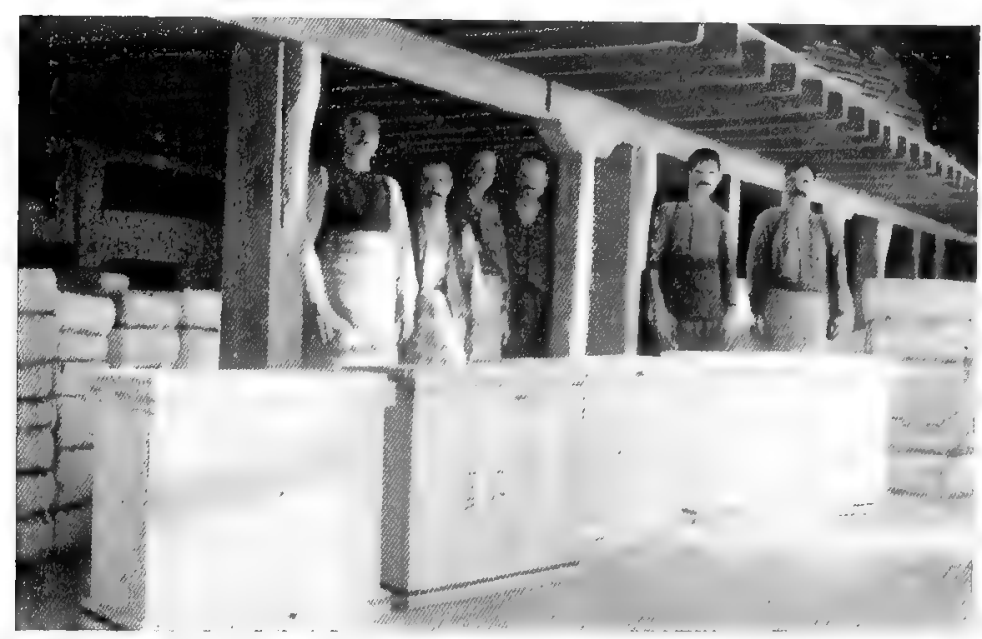

PHOTO TAKEN BX MR. I. B. DI M MJTHAR.

Cases containing bales of superior grades of 'Turkish tobacco, which are ready for shipment. The American Tobacco Company's buildings, Cavalla, Macedunia.

curing is completed in less than a rreek's time. One of the principal factors controlling the value of the leaf cured by this method is the colour, and the two prime conditions for success are the right kind of the soil and the proper control of the curing. The colour most desired is a characteristic bright lemon-yellow.

In the flue-curing method, just as in the air-curing 
process, the principal changes in composition brought about in the curing are dependent on the life activities of the minute cells of the leaf, and the nature of the changes in the two methods is the sime. The main difference lies in the extent or completeness of these changes. The typical bright rellow tobaccos is harrested riper than tobacco which is cured without the use of heat. Partly on this account and also because of the character of the soil on which it is grown, this type of leaf is relatively richer in starchy matter and poorer in orwanic nitrogenous materials. Because of the difference in composition combined with the effects of hish temperittures and more rapid drying, the green colour is remored much more rapidly. The rapid appearance of the yellow colour does not afford sufficient time for the transformation of all the starchy matter and as soon as this stage is reached the drying must be hastened so as to prevent any further change in colour. Fividently, then, the Hue curing method consists essentially in the hastening and shortening of the first stage in the air-curing process. while the second stage of the cure, made applarent br the development of the brown colour in the calse of cinir tobaco, is not allowed to take place at all.

The capacity of the air for holding moisture, and consequently its drying capacity, depends principally (n? its temperature ; and air which is already satturated hisis no drying power mutil its temperature is raised. S.tisfactory euring an only be acomplished by proper resulation of the rate ne drying ; and this depends chichly on the humidity of the atr in the barm. From these facts it is clear that in order to maintain a definite rate of dryin: by controlling the humidity, the temperature in the harn must hear a certain relation to that of the ontside ar ; 
and the difference in temperature inside and outside the barn will be influenced by the humidity of the outside air. In warm weather the temperature inside the barn must be higher than in cool weather ; and in rainy or in foggy seasons it must be higher than in clear, dry weather. In addition to temperature there is another equally important factor in controlling the humidity in

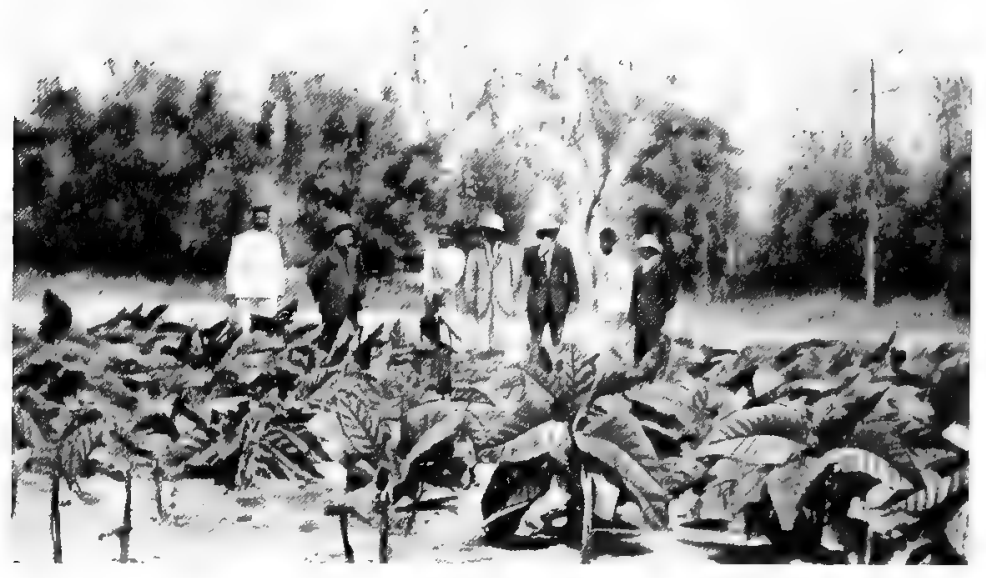

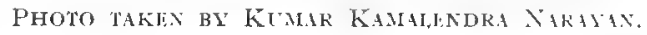

I field of country tobacco at Dinhata (Cooch Behar), partly harvested. The group consists of Maharajkumar Victor N. Narayan (fourth figure from the left), and some of the officers of the Cooch Behar State.

the barn, and consequently the rate of drying, and this is rentilation. If the barn were perfectly tight, the air within would, of course, soon be saturated; and the ineritable result would be that tobacco would sweat; that is, drops of water would collect on the surface of the leaves. The warm saturated air in the barn must, therefore, be constantly replaced by the cooler, less 
humid outside air ; and hence proper means of rentilition should be provided.

The completion of the curing proper is marked by the development of the rellow colour. The transformation from a green to a yellow colour, aloms with other attendant changes, takes place while the leaf is still living and if the leaf is quickly killed by heat, or by being rapidly dried out, it will be impossible t" remore the "reen colour. At temperature above I 25 " $\mathrm{F}$ the le th rapidly killed, so that this limit must not be exceeded during the rellowing process. The areatest dinger in the first stage of the curing, howerer, is that the leaf will dry out so rapidly as to prematurely kill it. The rellowing process may be accomplished at any temperature ranging between $s 0^{\circ}$ and $\mathrm{I} 20^{\circ} \mathrm{F}$, provided the humidity in the barn be properly manayed. Cire must be taken to avoid drving the leaf too ritpidly during the first stige of the cure ; but as it buins to rellow, the humidity in the barn must be materially decreased, by slowly rasing the temperature, and increasing the ventilation. As soon as the leaf has become rellow, the whole problem is to resulate the drying so as to freenent any further change in colour. This second st.lece of curing known as "fixing the colour", is the critical period and requires the closest attention. The anpearance of the rellow colour indicates that the le if hats reached the dying stage, but it still contains a largece anount of water. When the leaf tissue dies, all the moisture within the leaf is released, and will ranidly move fo the surfice, so that unless the moisture is prompty removed, the leaf will benin to turn al reddish brown collowr. This is called "sponging." To arobl this injury to the tobacen, the heat must be rised rery 
slowly, so as to kill the leaf tissue gradually, and, more important still, plenty of ventilation must be provided to take away the moisture. If the heat is increased too rapidly while the leaf is still full of sap, a greenish black discoloration will develop, which is known as "scalding" or "blistering".

The temperature should be maintained at from $130^{\circ}$ to $140^{\circ} \mathrm{F}$ until the leaf is completely dried out, which will require about ten to eighteen hours after the com-

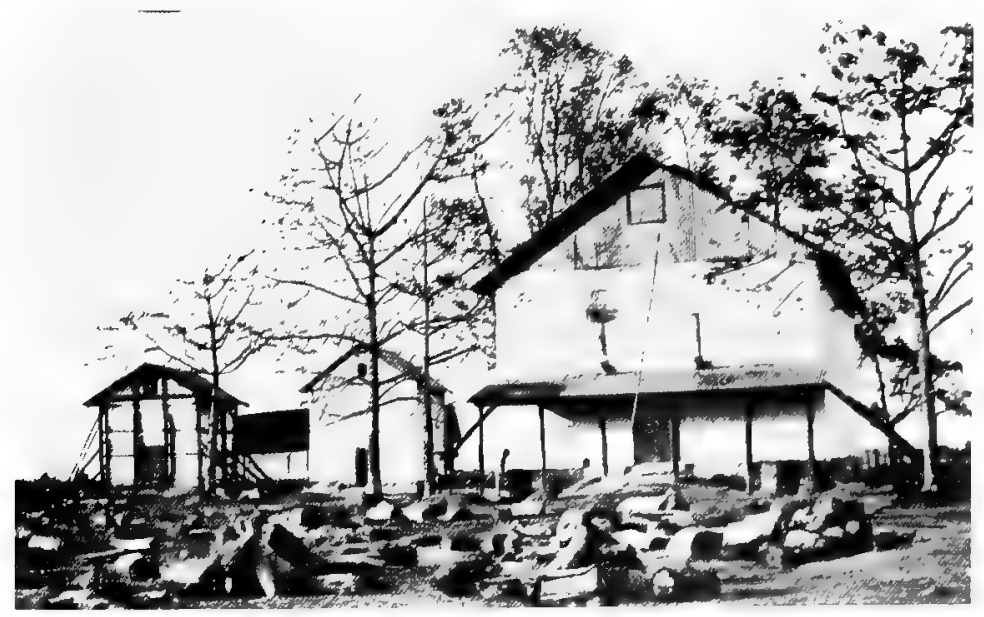

Photo TAKlin by Mr. I. B. DE Majumdar.

Flue curing sheds in the Cooch Behar State Tobacco Farm.

pletion of the yellowing process. All danger from sponging or scalding is now past, and it only remains to dry out the stems. The ventilators are now closed, and the temperature raised up to $165^{\circ}$ or $175^{\prime \prime} \mathrm{F}$ at the rate of about 5 degrees an hour. This latter temperature is maintained till all the stems are completely dried out. 


\section{INTRODUCTION OF SUPERIOR VARIETIES FROM OTHER COUNTRIES.}

So far we have dealt with two phases of improvement, vis: ( 1 ) by breceling and selection, and (2) by the adoption of up-to-date methods of curing; both of which directly apply to the indigenous crop), the cultivation of which has been going on in India for years. Now we shall deal with the question of introduction of superior varieties from other countries ; and growing and acclimatizing them in suitable soils, and under proper climatic conditions. There is a great demand for hish class tobacco in India, both for the manuficture of cisirs and cisarettes. The tobacco factorices in Calcutta, Madras, Nonglyy, Rangpur and other plices are sure to provide ample markets for superior varictic's of tubacco that may be introduced into this country. Su far attempts have been made in India to srow forcisn varieties of tohatew not un commercial but mostly on experimental scales. Several hundred matunds of "vellow tobacon" were suc-

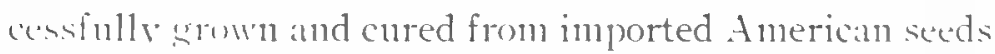
in the Cixch Behar Tohicen Farm, and sold to some of the above facturices at an average price of Rs. 3.5 pet matund (the best grades fetching R.s. on fer matund), anainst Rs. 5 to Io per mand of the indigenous product :rown by the cultivators. Sereral mannds of Simatral tobsecos were also srown at the comernment Foxperimental Farm at Burir Hat, Ramgpur, and fetched as much ils R.s. roO frer milund.

It must be observed that while the improvement of the indigenous fromed by proper curing, ete, is mot a diffeult affare, the intruluetion and acelimatisation of

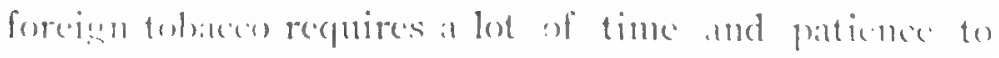


achieve success ; but finally the results obtained justify the experiments if judiciously carried on. The Cuban and Sumatra rarieties have been successfully grown in the United States. The results obtained go beyond all expectations. In the Paris Exhibition of I goo, the jury voted to the Florida-grown leaf 20 points of merit, and to the Sumatra grown leaf i 8 points. The Florida-grown leaf from Cuban seeds also received favourable consideration, being voted i 8 points of merit against i 8 points received by the Cuban product. The amount of patience and perseverance displayed by the tobacco growers of Florida, in their efforts to grow superior varieties from other countries, will be manifest from the following extracts* and their example may serve as an incentive to the tobacco-growers in this country:-

"In order to imporve the tobacco and adapt it to the trade demands, these concerns have indulged in all sorts of experiments, some of which have proved quite expensive. Howerer, they have met with such a degree of success as to warrant them in continuing the experimental work. There were many questions to be settled. First of all, What seed should be used? To settle this question, seed was obtained and tried from every part of the country. This point, however, was soon determined, and now there are only two varieties - grown in the state-Sumatra and Cuban, the Sumatra giving the style required for the wrapper, and the Cuban giving the filler qualities nearest the requirements of the trade. As each of these kinds of tobacco possesses the quality needed, the kind of soil best suited to each was the next point to be settled; then the proper fertilizer, the quantity necessary, and

\footnotetext{
From report No.62, Lnited States Department of Agriculture, "Cultivation of Cigar Leaf Tobacco in Florida" pp. 2I-22. Published I899.
} 
the proper cultivation had to be found out by nunnerous experiments. At first it was thought that but little fertilizer of any kind should be used. The ubruco was stet out early. yiven a distance in the drill of about 24 inches, and topped low ; that is, liot more than twelve or fourteen leaves were allowed to each stalk. The result was that the plants produced larse, coarse, undesirable leares. The next step was to give the tobacco less distance in the drill : Is inches were tried. The result was better but not sat isfactory. From time to time changes were made until now the plant: is siven 44 inches, the fertilizer is doubled, and the tobacco is topped higher, allowing at least sixteen leaves to each stalk. The result is that the leaves are of the desirable sime and finer in quality and appearance.

"When the Sumatra seed wiss first introduced into Florida, the land selected, the amount of fertilizers used, and the methods of cultivation and harresting employed, were the same as those , ractised in growing the Cuban variety. With this treatment, Sumatra proved to be an absolute failure; many anandoned the sed, while others continued to experiment. It was sonn found that the wil had to be excedingly rich, the sumth quick ; that low topping was ruinous, and that each stalk should have from twenty-four to thirty leares, wording to the stremeth of the soil. When the land was excedingly rich, it was found best nest to top at all, but to allow the plants to guts: bloom. Then the leares womld be of desirable sime, thin and smonth; wheress if topped, the leatses monld curl and thicken. This tohuce is also cromeded i.te, the drill, the plants lecing enen only from 12 to 14

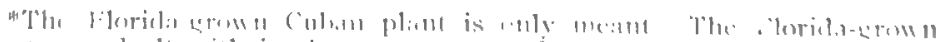

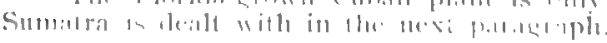


inches. The growth is rapid ; the top leares soon serve as a shade for the middle and lower leares, and the results have been most gratifying. New land proved to be more desirable for this variety of tobacco ; and it was noticed that when trees were left standing in the field, the plants shaded by trees were far superior to the plants not so shaded. From this the idea of building artificial shade had its birth. It was also found that no good results could be obtained if the plants were cut, but the leares should be primed off just as they ripen, and at a very early stage of ripeness."

"Iarvesting the leaves singly without the stalk is called "priming". 


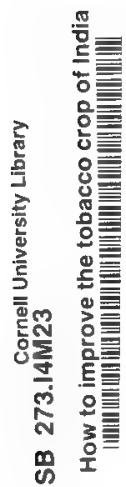





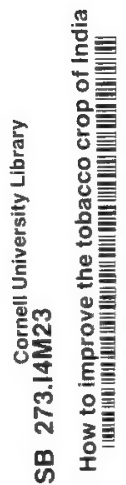




\section{Fressboara}

Pamphlet

Binder

Gaylord Bros.Ine.

Maker

Syracuse, IV. Y.

PRT. Jall 21, 1909 
